\title{
Pengembangan Media Pembelajaran Matematika dengan Animasi Menggunakan Aplikasi Swishmax
}

\author{
Ahmad Charissudin ${ }^{1}$, Farida $^{2}$, Rizki Wahyu Yunian Putra ${ }^{3}$ \\ 1, 2, 3 Universitas Islam Negeri Raden Intan Lampung \\ *ahmadcharissudin123@gmail.com
}

\begin{abstract}
ABSTRAK
Penelitian ini dilakukan bertujuan untuk mengetahui pengembangan, kelayakan, dan kemenarikan dari media pembelajaran matematika dengan animasi menggunakan aplikasi swishmax untuk siswa sekolah menengah pertama kelas VIII. Research and development adalah jenis penelitian yang digunakan dalam penelitian ini dengan memanfaatkan model ADDIE dalam tahapannya. ADDIE adalah Analyze, Desaign, Development, Implimentation, dan Evaluation. Uji coba dalam penelitian ini bertempatkan di MTs Nurul Iman Jati Agung Lampung Selatan. Uji kelayakan dalam penelitian ini dilakukan dengan cara memberika angket kepada para ahli mengenai media pembelajaran yang telah dikembangkan. Hasil yang diperoleh dari para ahli sebesar 3, 43 dan 3, 40 dengan kriteria layak digunakan. Uji kemenarikan dari penelitian ini adalah dengan cara memberikan angket respon peserta didik mengenai media pembelajaran matematika yang telah dikembangkan dan hasil dari angket respon peserta didik yang telah diberikan diperoleh hasil sebesar 3, 42 dengan kriteria menarik. Kemudian dapat disimpulkan bahwa media pembelajaran matematika dengan animasi menggunakan aplikasi swishmax layak dan menarik untuk dimanfaatkan dalam pembelajaran didalam kelas.
\end{abstract}

Kata kunci: media pembelajaran, matematika, Swishmax.

\section{ABSTRACT}

This study was conducted to determine the development, feasibility, and attractiveness of animationbased mathematics learning media using the Swishmax application for grade VIII junior high school students. Research and development is a type of research used in this study by utilizing the ADDIE model in its stages. ADDIE is Analyze, Design, Development, Implimentation, and Evaluation. The trials in this study were located at MTs Nurul Iman Jati Agung Lampung Selatan. The feasibility test in this study was carried out by giving a questionnaire to experts regarding the learning media that had been developed. The results obtained from the experts were 3, 43 and 3, 40 with criteria worthy of use. The test of the attractiveness of this research is by giving a questionnaire to the responses of students regarding the mathematics learning media that has been developed and the results of the questionnaire responses of students that have been given are 3, 42 with interesting criteria. Then it can be concluded that animation-based mathematics learning media using the Swishmax application is feasible and interesting to be used in classroom learning.

Keywords: learning media, mathematics, Swishmax. 


\section{PENDAHULUAN}

Perkembangan teknologi informasi yang semakin cepat, sudah semestinya harus bisa digunakan untuk menunjang proses pembelajaran. Seharusnya perkembangan teknologi dan informasi yang semakin maju dapar berjalan beriringan dengan perkembangan kemajuan dunia pendidikan. Pemanfaatan teknologi dan informasi sebagai salah satu perangkat pembelajaran untuk menunjang kegiatan belajar mengajar merupakan salah satu bentuk dari penerapan tekologi yang semakin cepat didalam dunia pendidikan. Khususnya pendidikan di Indonesia (Maskur dkk., 2017).

Menurut (Putra \& Anggraini, 2016) Matematika merupakan salah satu mata pelajaran yang cukup berpengaruh terhadap kemajuan perkembangan zaman. Oleh sebab itu menjadi dasar pokok berkembangnya suatu ilmu pengetahuan dalam bidang-bidang yang lain. Selain dari pada itu, tujuan dari pembelajaran matematika ialah didalam kehidupan sehari-hari, nantinya peserta didik mampu menerapakan teori-teori matematika yang telah dipelajarinya secara akurat agar dapat terwujud sumber daya manusia yang bermutu (Akbar \& Komarudin, 2018).

Menurut (Adiwijaya dkk., 2015) Matematika adalah mata pelajaran yang telah diajarkan dari tingkatan pendidikan yang paling mendasar hingga tingkatan pendidikan yang paling tinggi. Akan tetapi fakta yang ada hingga saat ini hasil belajar dari peserta didik masih tergolong rendah dengan sebab matematika dirasa sulit untuk dipelajari oleh peserta didik (Yupinus dkk., 2020). Oleh karenanya, dengan menggunakan teknologi yang tersedia untuk dunia pendidikan misalnya sebuah media pembelajaran yang bermacam-macam didalam kegiatan belajar mengajar (KBM), dapat menghasilkan pembelajaran yang berfaedah dan mengasyikkan terlebih di mata pelajaran matematika sehingga menghapus pemikiran peserta didik yang menganggap bahwa matematika itu susah. Lebih-lebih kita dapat turut membuntuti proses sirkulasi kemajuan zaman.

Mengacu pada kurikulum 2013 yang telah diberlakukan sejak tahun 2013, mengharuskan guru untuk selalu memanfaatkan teknologi, informasi, dan komunikasi untuk meningkatkan efisiensi pembelajaran (Kementrian Pendidikan dan Kebudayaan, 2013). Hal tersebut dapat dimulai dengan mempelajari bermacam-macam software untuk membuat media pembelajaran yang disesuaikan dengan kebutuhan siswa (Pradipta, 2013).

Menurut (Supriadi, 2015) dalam pembelajaran matematika, guru jarang menggunakan media pembelajaran yang mampu memberikan visualisasi secara jelas tentang kejadiankejadian yang terkait dengan mata pelajaran tersebut, sehingga konsep materi-materi mata pelajaran matematika kurang dapat dikuasi siswa. Penggambaran yang diperlihatkan secara menarik, dapat digerakkan dan dirubah bentuk juga ukurannya, menyediakan kesempatan kepada siswa agar melaksanakan pendalaman dan pengamatan dengan mudah. MTs Nurul Iman Jati Agung Lampung Selatan, sampai saat ini belum memiliki media pembelajaran yang interaktif untuk mata pelajaran matematika, keadaan sekolah yang dicukupi sarana seperti laptop, LCD, dan speaker hakikatnya amat membantu agar guru memaparkan materi pada

peserta didik dengan memanfaatkan media visual (Rinayanti, komunikasi pribadi, 13 Februari 2020).

Berdasarkan pra-penelitian yang telah penulis lakukan, penulis memperoleh data nilai ulangan harian siswa dan hasil dari ulangan harian tersebut sebanyak 66, 67 \% siswa kelas VIII 
A belum mencukupi KKM yang telah ditentukan atau sebanyak 20 siswa dari 30 siswa yang masih belum mencukupi KKM. Sedangkan siswa yang telah mencapai KKM hanya 10 orang atau 33, 33 \% saja. Penulis berpendapat bahwa salah satu faktor yang menyebabkan hasil belajar siswa rendah adalah kurangnya guru dalam menggunakan media pembelajaran terlebih lagi media visual yang dapat membantu siswa dalam proses belajar dan memahami materi matematika.

Gerlach \& Ely berpendapat bahwa media adalah manusia, materi ataupun peristiwa yang membentuk kondisi yang dapat menjadikan peserta didik dapat mendapatkan pengetahuan, keterampilan, atau sikap. Dalam pengertian ini, buku, guru, teks, dan area sekolah merupakan bagian dari media. Apabila dikhususkan, penjelasan media dalam sistem belajar mengajar lebih dimaknai sebagai instrumen grafik, photografis, atau elektronis untuk mengetahui, mereaksi, dan membentuk ulang penjelasan optis atau lisan yang telah diperoleh (Arsyad, 2010).

Dalam (Ariyati \& Misriati, 2016), Heinich dan Molenda berpendapat, ada 6 bentuk pokok media pembelajaran, yaitu teks, media audio, media visual, media proyeksi gerak, miniatur, dan manusia. Menurut suryanto yang dikutip (Akmaludin, 2013) Animasi ialah suatu sekuen gambar yang diungkap dengan batas masa tertentu sehingga terbentuk suatu gambar bergerak, khayalan gerakan tersebut bisa berlangsung dengan cepat, dan sekelompok gambar yang memiliki aktivitas secara berangsur-angsur dari tiap-tiap pecahan wujud gambar tersebut.

Swishmax termasuk software hasil peningkatan dan program v. 2. Pada mulanya orang mengetahui software ini hanya berguna sebagai tool untuk membuat animasi teks, sehingga ketenaran software ini kalah jauh dibandingkan dengan software-software pembangun animasi lainnya, namun seiring dengan perkembangan dunia animasi, swish mulai bangkit dengan meluncurkan generasi baru dari swish v. 2, yaitu swishmax (Mulyanta, 2010). Menurut (Fajarwati, 2016) Kelebihan dari swishmax sendiri adalah:

1. Dapat membentuk animasi gambar secara lembut melalui warna-warna yang cemerlang sehingga mampu mempercepat stimulan yang diberikan guru terhadap siswa.

2. Penyampaian yang lugas tetapi sangat efisien, sebab dilengkapi simbol berupa tombol yang bisa dikonversi dengan script sesuai kemauan.

3. Bisa menyampaikan berbagai jenis media baik audio, visual, maupun audio-visual seperti gambar, suara, teks, dan film.

4. Bisa diputar dengan cepat melalui pemutaran flash (Macromedia Flash Player).

5. Mempunyai keunggukan untuk membentuk pembelajaran menjadi bertambah interaktif, sebab swishmax dipenuhi bermacam-macam script yang bermuatan perintah-perintah dan sanggup dijalankan layaknya sebuah aplikasi/software.

Sedangkan menurut (Efendi dkk., 2019) kekurangan dari swishmax, yaitu:

1. Membutuhkan peralatan tertentu dalam penyampaian.

2. Membutuhkan kemampuan tertentu dalam pembuatan.

3. Membutuhkan tenaga listrik.

Berdasarkan uraian di atas, maka penulis merasa perlu diadakannya penelitian dengan judul Pengembangan Media Pembelajaran Matematika Dengan Animasi Menggunakan Aplikasi Swishmax. Pengembangan media pembelajaran ini selain untuk memudahkan perserta didik dalam memahami materi matematika, juga diharapkan dapat membantu pendidik dalam proses pembelajaran di dalam kelas serta dengan adanya pengembangan media pembelajaran dengan animasi ini dapat menjadikan peserta didik lebih kreatif dan juga aktif. 
Telah dilakukan penelitian sebelumnya oleh (Fredy, 2014), yang dalam penelitian tersebut dihasilkan media pembelajaran interaktif untuk siswa SMA kelas X dengan materi gerak melingkar beraturan berbantuan swishmax-4 dan dikategorikan layak dalam pembelajaran fisika. Pembaharuan dari penelitian-penellitian sebelumnya, yaitu penelitian ini dilakukan di kelas VIII pada mata pelajaran matematika dan materi lingkaran selain dari pada itu media yang dikembangkan terdapat efek-efek atau animasi yangt dapat membantu siswa dalam memahami matematika terkhusus pada materi lingkaran. Pernah dilakukan penelitian oleh (Basmalah, 2013) diperoleh hasil yang sangat tinggi dilihat dari persentase ketuntasan siswa pada soal postes sebesar $96,67 \%$ dan disimpulkan media pembelajaran yang dihasilkan berdampak baik terhadap prestasi belajar karena diperoleh persentase $76,67 \%$ siswa mengalami kenaikan nilai.

\section{METODE PENELITIAN}

Jenis Penelitian yang akan penulis gunakan yaitu Research and Development (R\&D) atau penelitian dan pengembangan. Menurut (Sugiono, 2012: 407) Research and Development adalah sebuah metode penelitian yang digunakan untuk menghasilkan produk. Dengan kata lain penelitian ini bertujuan untuk mengembangkan sebuah produk dan menguji layak dan menarik tidaknya produk tersebut. Penelitian pengembangan ini menggunakan model penelitian ADDIE. Pemilihan model ini didasari atas pertimbangan model ini mudah dipahami, selain itu juga model ini dikembangkan secara sistematis dan berpijak pada teoritis media pembelajaran yang dikembangkan. ADDIE adalah singkatan dari Analyze, Design, Development, Implementation, Evaluation (Rayanto, 2020).

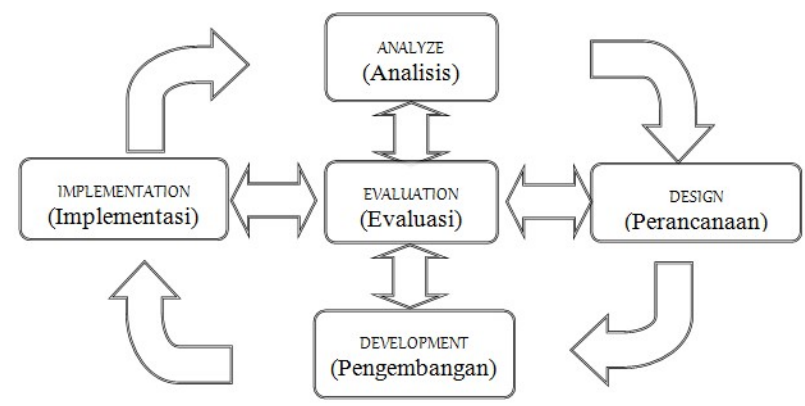

Gambar 1. Diagram Tahap Model ADDIE

Produk yang akan dihasilkan dari penelitian ini dengan memanfaatkan ADDIE adalah media pembelajaran berbentuk video pembelajaran yang dirancang dengan memanfatkan aplikasi swishmax. Tahap analyze melahirkan tahap untuk mengkaji keperluan media pembelajaran, apakah sinkron atau tidak dengan keperluan di sekolah. Proses analisis yang dilaksanakan adalah mengkaji media pembelajaran yang selaras dengan kompetensi dasar yang berlandaskan pada kurikulum, kebutuhan, individual peserta didik sebagai subjek penelitian . Tahap Design ialah membentuk desain media yang akan dibuat (Rayanto, 2020).

Pada tahap development ialah aktifitas pengembangan yang mencakup aktivitas penyusunan media pembelajaran. Pengumpulan materi, pengetikan, pembuatan gambar-gambar, dan lain-lain. Tahapa implementation adalah tahapan untuk mengevaluasi 
media yang kemudian digunakan acuan guna merevisi media pembelajaran yang dibuat . Tahap evaluation yaitu penulis melaksanakan evaluasi (evaluation) yang mencakup evaluasi sumatif dan evaluasi formatif. Dalam penilaian ini memanfaatkan evaluasi formatif guna memperbaiki produk yang telah dikembangkan dan evaluasi sumatif guna melihat kelayakan dan kemenarikan media pembelajaran yang telah dikembangkan (Rayanto, 2020).

Hasil dari skor penilaian masing-masing validator ahli kemudian dicari rata-rata penilaian dan dikonversikan ke pernyataan untuk menentukan kevalidan dan kelayakan media pembelajaran matematika dengan animasi menggunakan swishmax-4 pada materi lingkaran. Penkonversian skor menjadi pertanyaan penilaian ini (Putra dkk., 2017) adalah sebagai berikut.

Tabel 1. Kriteria Validasi

\begin{tabular}{ccc}
\hline Skor Kualitas & Kriteria Kelayakan & Keterangan \\
\hline $3,25<\bar{x} \leq 4,00$ & Valid/Sangat layak digunakan & Tidak revisi \\
$2,50<\bar{x} \leq 3,25$ & Cukup valid/layak digunakan & Revisi sebagian \\
$1,75<\bar{x} \leq 2,50$ & Kurang valid/kurang layak digunakan & Revisi sebagian, pengkajian ulang \\
$1,00<\bar{x} \leq 1,75$ & Tidak valid/tidak layak digunakan & Revisi total \\
\hline
\end{tabular}

Hasil dari penilaian peserta didik kemudian dicari dan dihitung rata-rata penilaian dan selanjutnya dikonversikan ke pernyataan untuk melihat kriteria terkait kemenarikan dari media yang telah dibuat. Pengkonvensian skor menjadi pernyataan penilaian (Zaky dkk., 2018) terangkum pada Tabel 2.

Tabel 2 Kriteria Uji Kemenarikan

\begin{tabular}{cl}
\hline Skor Kualitas & \multicolumn{1}{c}{ Kriteria } \\
\hline $3,25<\bar{x} \leq 4,00$ & Sangat menarik \\
$2,50<\bar{x} \leq 3,25$ & Menarik \\
$1,75<\bar{x} \leq 2,50$ & Kurang menarik \\
$1,00<\bar{x} \leq 1,75$ & Sangat kurang menarik \\
\hline
\end{tabular}

\section{HASIL DAN PEMBAHASAN}

Pertama kali yang penulis lakukan dalam penelitian ini adalah tahap Analyziz (analisis), pada tahap ini peneliti menganalisis kebutuhan untuk mengetaui permasalahan yang terjadi di MTs Nurul Iman Jati Agung Lampung Selatan dan hasil analisis tersebut berdasarkan wawancara dengan pendidik yang mengampu mata pelajaran matematika yakni pembelajaran matematika didalam kelas saat ini masih berporos pada pendidik. Pada materi lingkaran media pembelajaran yang sering digunakan adalah buku cetak, power point, LKS, dan alat peraga. Peserta didik juga masih mengalami kesulitan dalam memahami materi lingkaran dalam proses pembelajaran yang memanfaatkan media-media tersebut. Kemudian penulis melanjutkan ke tahap analisi kurikulum. MTs Nurul Iman Jati Agung Lampung Selatan kurikulum yang digunakan yaitu kurikulum 2013.

Selanjutnya adalah analisis karakteristik peserta didik, dan hasil dari analisis karakteristik akan disesuaikan dengan isi materi yang ada dalam media pembelajaran dengan animasi menggunakan aplikasi swishmax. Selanjutnya yaitu tahap Design (perancangan) yang pada tahap ini proses penyusunan desain media pembelajaran yang ajan dikembangkan, penyajian materi media pembelajaran yang akan dikembangkan yang akan disesuaikan dengan 
kompetensi dasar, dan perencanaan instrumen yang berbentuk angket validasi dan respon peserta didik yang digunakan untuk mengevaluasi media pembelajaran yang telah dikembangkan.

Usai dari tahap desain kemudian dilanjutkan ke tahap Development (pengembangan). Tahap ini adalah proses pembuatan media pembelajaran dengan animasi menggunakan aplikasi swishmax. Setelah proses pembuatan kemudia media pembelajaran yang telah dibuat dikonsultasikan kepada dosen pembimbing untuk mendapatkan saran dan masukan sebelum berlanjut ketahap Implementation. Setelah tahap Development selesai, kemudian berlanjut ketahap Implementation. Dalam tahap implementation ini penulis melaksanakan validasi media dan uji coba produk. Validasi media pembelajaran yang telah dibuat memiliki tujuan untuk mengtahui kekurangan dan kesalahan dari media pembelajaran dengan animasi menggunakan aplikasi swishmax serta kritik dan saran dari validator digunakan untuk memperbaiki media pembelajaran yang sedang dikembangkan.

Pada tahap validasi ini dilaksanakan oleh enam orang ahli yaitu 3 orang ahli media dan 3 orang ahli materi. Hasil penilaian dari para ahli media berada diangka 3,39 sampai dengan 3,56 dengan kriteria "Layak Digunakan".Kesimpulan dari hasil penilaian tersebut adalah media pembelajaran yang sedang dikembangkan dinyatakan layak dan valid untuk digunakan dalam pembelajaran dan tidak adanya perbaikan. Penyajian dalam bentuk diagram pada penilian para ahli media dapat dilihat dalam Gambar 2.

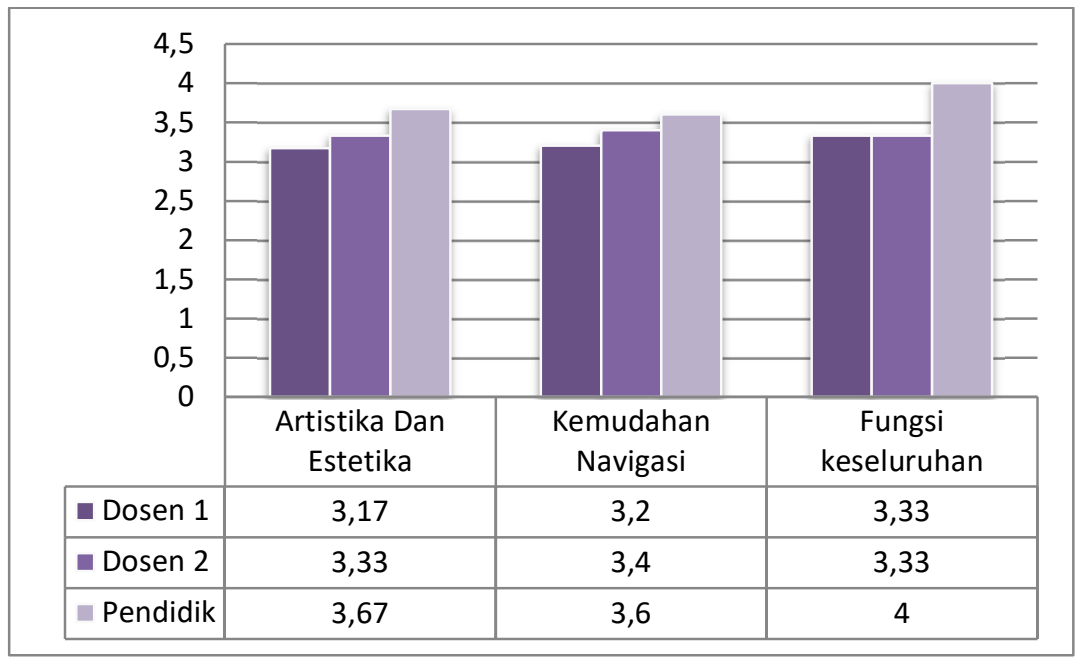

Gambar 2. Diagram Penilaian Ahli Media

Hasil penilaian dari para ahli materi berada diangka 3,33 sampai dengan 3,58 dengan kriteria "Layak Digunakan". Kesimpulan dari hasil penilaian tersebut adalah media pembelajaran yang sedang dikembangkan dinyatakan layak dan valid untuk digunakan dalam pembelajaran dan tidak adanya perbaikan. Penyajian dalam bentuk diagram pada penilian para ahli media dapat dilihat dalam Gambar 3. 


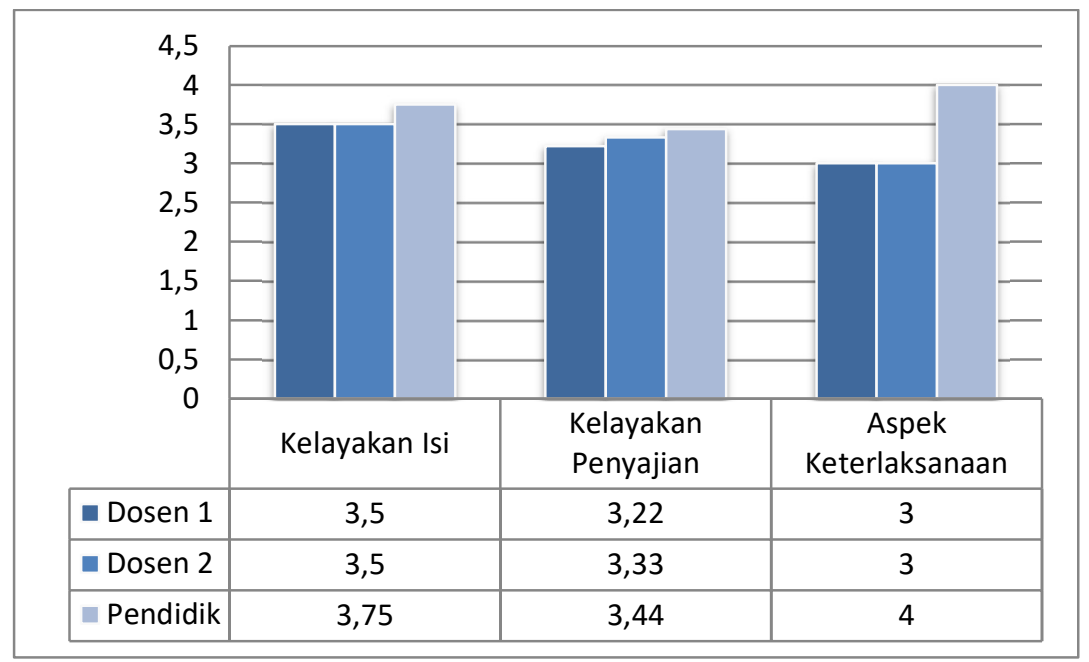

Gambar 3. Diagram Penilaian Ahli Materi

Tahap selanjutnya adalah tahap uji coba produk. Pada tahap ini penulis melakukan uji coba produk dalam skala kecil dan skala besar, media pembelajaran yang telah dikembangkan. Uji coba produk skala kecil dan skala besar dilakukan untuk mengetahui kemenarikan dari media pembelajaran dengan animasi menggunakan aplikasi swishmax dengan memberikan angket respon kepada peserta didik. Uji coba produk skala kecil dilakukan dengan 10 orang peserta didik yang dipilih secara random dan diperoleh hasil dengan nilai rata-rata 3, 15 dan berkriteria "menarik".

Kemudian uji coba produk dalam skala besar dilakukan dengan 29 orang peserta didik dan diperoleh hasil dengan nilai rata-rata 3,25 dan berkriteria "menarik". Berdasarkan nilai ratarata yang diperoleh dalam uji coba produk skala besar dan kecil, media pembelajaran dengan animasi menggunakan palikasi swishmax telah memenuhi aspek kemenarikan yang kemudian layak untuk digunakan dalam proses pembelajaran kepada peserta didik.Kemudian dilaksanakan uji coba skala besar dengan 29 peserta didik dari kelas VIII B guna mengetahui kemenarikan media pembelajaran dengan animasi menggunakan aplikasi swishmax yang telah dikembangkan secara luas. Hasil analisis data di dapatkan dari uji coba skala besar memiliki kriteria "menarik" dengan nila rata-rata 3,25. Hasil analisi data dari respon peserta didik dalam skala kecil dan skala besar dapat dilihat pada Gambar 4.

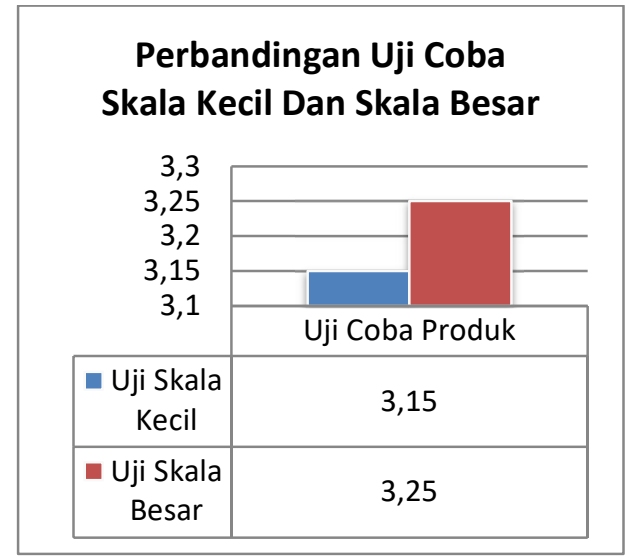

Gambar 4. Grafik Perbandingan Uji Coba Skala Kecil Dan Skala Besar 
Selanjutnyaa adalah tahap evaluation (evaluasi) yang merupakan tahap akhir dari model ADDIE. Tahapan evaluasi yang ada pada model ADDIE selalu dilaksanakan pada setiap tahapan-tahapan yang ada pada model ADDIE. Tahapan evaluasi memegang peran penting dalam mengevaluasi efektivitas dan kualitas media pembelajaran yang sedang dikembangkan.

Kelebihan dari media pembelajaran dengan animasi menggunakan aplikasi swishmax ini adalah dapat diaplikasikan dengan mudah menggunakan laptop dan PC (komputer), dapat digunakan secara offline maupun online, memuat gambar dan animasi dari setiap penyajian materi, dan dapat digunakan dengan mudah.

Sedangkan kekurangan dari media pembelajaran dengan animasi menggunakan aplikasi swishmax adalah belum dapat diakses menggunakan handphone dan membutuhkan listrik jika diakses menggunakan PC dan ditampilkan melalui LCD proyektor.

\section{SIMPULAN}

\subsection{Simpulan}

Kesimpulan pada penelitian dan pengembangan media pembelajaran dengan animasi menggunakan aplikasi swishmax untuk siswa sekolah menengah pertama kelas VIII adalah sebagai berikut.

1. Penelitian dan penngembangan ini menggunakan model ADDIE dan menghasilkan berupa produk video pembelajaran yang dengan animasi menggunakan aplikasi swishmax untuk siswa sekolah menengah pertama kelas VIII dengan materi dalam media pembelajaran ini adalah lingkaran.

2. Penilaian para ahli mengenai kelayakan media pembelajaran dengan animasi menggunakan aplikasi swishmax untuk siswa sekolah menengah pertama kelas VIII menperoleh hasil dengan kategori "layak digunakan”. Sedangkan untuk kemenarikan media pembelajaran dengan animasi menggunakan aplikasi swishmax untuk siswa sekolah menengah pertama kelas VIII berdasarkan hasil uji coba produk dalam skala kecil dan skala besar dengan memberikan angket respon kepada peserta didik, keduanya memperoleh hasil dengan kriteria "menarik".

\subsection{Saran}

Penulis memberikan saran berdasarkan penelitian yang telah penulis lakukan adalah sebagai berikut.

1. Diperlukannya pengembangan Media pembelajaran dengan aplikasi swishmax dalam materi yang lain dan menyesuaikan kebutuhan masing-masing.

2. Dalam penelitian ini uji coba hanya dilakukan uji kemenarikan, dan diharapkan untuk ada yang melakukan uji coba untuk tahap efektivitas.

3. Media pembelajaran dengan aplikasi swishmax untuk siswa sekolah menengah pertama kelas VIII ini diharapkan dapat ditingkatkan dalam segi tampilan dan isi agar menarik dan efektif lagi

4. Pengimplikasian dalam penelitian ini hanya terfokus dalam satu kelas. Diharapkan untuk peneliti yang akan datang dapat di implikasikan dalam skala yang lebih besar. 
5. Media pembelajaran dengan aplikasi swishmax untuk siswa sekolah menengah pertama kelas VIII ini diharapkan dapat dimanfaatkan menggunakan handphone dan alat elektronik lainnya.

6. Media pembelajaran dengan aplikasi swishmax untuk siswa sekolah menengah pertama kelas VIII ini dapat diujikan disekolah-sekolah lain.

\section{DAFTAR PUSTAKA}

Adiwijaya, M., Kodrat, I. S., \& Yuli, C. (2015). Perancangan Game Edukasi Platform Belajar Matematika Dengan Android Menggunakan Construct 2. Transient: Jurnal Ilmiah Teknik Elektro, 4(1), 33-128.

Akbar, R. R. A., \& Komarudin, K. (2018). Pengembangan Video Pembelajaran Matematika Berbantuan Media Sosial Instagram sebagai Alternatif Pembelajaran. Desimal: Jurnal Matematika, 1(2), 15-109.

Akmaludin, A. (2013). Analisis Perancangan Animasi Interaktif Pembelajaran Anatomi Otak Manusia (Pengujian: Whitebox, Matrix Graphics, Blackbox, dan Metode Tabulasi Sederhana)(Studi Kasus: Madrasah Tsanawiyah Negeri 25 Jakarta Timur). Techno Nusa Mandiri: Journal of Computing and Information Technology, 10(2), 143-152.

Ariyati, S., \& Misriati, T. (2016). Perancangan animasi interaktif pembelajaran asmaul husna. Jurnal Teknik Komputer, 2(1), 116-121.

Arsyad, A. (2010). Media Pembelajaran. RajawaliPers.

Basmalah, Y. N. (2013). Pengembangan Media Pembelajaran Matematika Dengan Multimedia Interaktif Menggunakan Software Swish Max dengan Pendekatan Matematika Realistik pada Pokok Bahasan Luas dan Volume Bangun Ruang Sisi Datar. Yogyakarta: UIN Sunan Kalijaga.

Efendi, M., Mardiah, A., \& Despi, R. (2019). Pengembangan Media Pembelajaran Ilmu Pengetahuan Alam Dengan Swishmax Di Min 2 Palembang. Al-Muddarris: Journal Of Education, 191.

Fajarwati, S. (2016). Media pembelajaran animasi swishmax sebagai alternatif untuk siswa SD yang berkesulitan belajar pada materi bangun ruang. Probisnis, 9(1).

Fredy, B. (2014). Pengembangan Media Pembelajaran Interaktif Menggunakan Swishmax-4 Pada Materi Gerak Melingkar Beraturan Untuk Meningkatkan Prestasi Belajar Siswa Sma Kelas X. SKRIPSI Jurusan Fisika - Fakultas MIPA UM, O(0), Article 0. http://karyailmiah.um.ac.id/index.php/fisika/article/view/36217

Kementrian Pendidikan dan Kebudayaan. (2013). Peraturan Menteri Pendidikan Dan Kebudayaan No. 65 Tentang Standar Proses Pendidikan Dasar Dan Menengah. Kementrian Pendidikan dan Kebudayaan.

Maskur, R., Nofrizal, N., \& Muhammad, S. (2017). Pengembangan Media Pembelajaran Matematika dengan Macromedia Flash. Al-Jabar : Jurnal Pendidikan Matematika, 8(2), 86-177.

Mulyanta. (2010). Tutorial Membangun Multimedia Interaktif Media Pembelajaran. Universitas Atmajaya.

Pradipta, K. R. (2013). Pengembangan Media Pembelajaran Fisika Dengan Multimedia dengan Menggunakan Swishmax 4 pada Materi Kinematika Gerak Lurus untuk Siswa SMA. 
SKRIPSI Jurusan Fisika - Fakultas MIPA UM, O(0), Article 0. http://karyailmiah.um.ac.id/index.php/fisika/article/view/24852

Putra, R. W. Y., \& Anggraini, R. (2016). Pengembangan Bahan Ajar Materi Trigonometri Berbantuan Software iMindMap pada Siswa SMA. Al-Jabar: Jurnal Pendidikan Matematika, 7(1), 39-47. https://doi.org/10.24042/ajpm.v7i1.129

Putra, R. W. Y., Nurwani, N., Putra, F. G., \& Putra, N. W. (2017). Pengembangan Desain Didaktis Bahan Ajar Materi Pemfaktoran Bentuk Aljabar pada Pembelajaran Matematika SMP. NUMERICAL: Jurnal Matematika Dan Pendidikan Matematika, 97-102. https://doi.org/10.25217/numerical.v1i2.133

Rayanto, Y. H. (2020). Penelitian Pengembangan Model Addie Dan R2d2: Teori \& Praktek. Lembaga Academic \& Research Institute.

Rinayanti. (2020, Februari 13). Wawancara Dengan Guru Matematika MTs Nurul Islam [Komunikasi pribadi].

Sugiono. (2012). Metode Penelitian Dan Pengembangan. Alfabeta.

Supriadi, N. (2015). Pembelajaran Geometri Dengan Geogebra Sebagai Upaya Meningkatkan Kemampuan Komunikasi Matematis. Al-Jabar: Jurnal Pendidikan Matematika, 6(2), 99-109.

Yupinus, L., Ichsan, I., \& Ardiawan, Y. (2020). Pengembangan Perangkat Pembelajaran Matematika dengan Pendekatan Matematika Realistik pada Pokok Bahasan Tabung untuk SMP Negeri 2 Nanga Taman Kelas IX. Square: Journal of Mathematics and Mathematics Education, 2(1), 61-72.

Zaky, M. A., Muhammad, S., \& Farida. (2018). Pengembangan Media Android dalam Pembelajaran Matematika. TRIPLE S: Journals Of Mathematics Education, 1(1). https://jurnal.unsur.ac.id/triple-s/article/view/377 